\title{
Removal of COD, ammoniacal nitrogen and colour from stabilized landfill leachate by anaerobic organism
}

\author{
Mohamad Anuar Kamaruddin • Mohd Suffian Yusoff • \\ Hamidi Abdul Aziz • Nur Khairiyah Basri
}

Received: 7 August 2012/ Accepted: 28 January 2013/Published online: 16 February 2013

(C) The Author(s) 2013. This article is published with open access at Springerlink.com

\begin{abstract}
This study was conducted to investigate the treatment performance of anaerobic organism for stabilized leachate under ambient air condition. The treatability of landfill leachate was tested under various influences including $\mathrm{pH}$, dosage of anaerobic organism and contact time. Laboratory experiment revealed that anaerobic organism was in progressive state when the leachate in neutral condition. At this phase, the removal efficiency of chemical oxygen demand (COD), ammoniacal nitrogen $\left(\mathrm{NH}_{3}-\mathrm{N}\right)$ and colour of $76.84,59.44$ and $46.2 \%$, were experimentally attained. The experimental results also showed that the the optimum variables condition was established at $\mathrm{pH} 7$ of leachate sample, dosage of $100 \mathrm{~mL}$ of anaerobic organism and required 14 days to reduce the $\mathrm{COD}, \mathrm{NH}_{3}-\mathrm{N}$ and colour pollutants to $65.5,60.2$ and $46.3 \%$, respectively. The preliminary investigation shows that the anaerobic organisms were able to remediate leachate pollutants by the microbial activity in the leachate sample under ambient air condition.
\end{abstract}

Keywords Landfill leachate - Anaerobic organism · $\mathrm{COD} \cdot \mathrm{NH}_{3}-\mathrm{N} \cdot$ Colour

\section{Introduction}

Landfilling is the primary means of municipal solid waste disposal in many countries worldwide owing to its economic advantages and minimum technology being practiced. Contamination of surface and ground water through

M. A. Kamaruddin · M. S. Yusoff $(\square)$.

H. A. Aziz · N. K. Basri

School of Civil Engineering, Universiti Sains Malaysia,

14300 Nibong Tebal, Pulau Penang, Malaysia

e-mail: suffian@eng.usm.my leachate; soil contamination through direct waste contact or leachate; air pollution through the burning of wastes and the uncontrolled release of methane by anaerobic decomposition of waste (Aziz et al. 2010) are some of the effects of landfilling activities. In addition, landfill leachate produced from landfill sites consists of contaminated pollutants that is very difficult to deal with (Umar et al. 2010). If not properly treated and safely disposed, leachate can migrate to soil and subsoils which might cause severe damage to eco-system of land and receiving water. Landfill leachate contains pollutants that can be categorized into four groups [dissolved organic matter, inorganic macrocomponents, heavy metals, and xenobiotic organic compounds (Kjeldsen et al. 2002)] as consequence of the existing waste disposal practice. Organic content of leachate pollution is generally measured by chemical oxygen demand (COD) and biochemical oxygen demand $\left(\mathrm{BOD}_{5}\right)$. Leachate is also rich in ammonia, halogenated hydrocarbons suspended solid, significant concentration of heavy metals and inorganic salts (Renou et al. 2008; Umar et al. 2010; Bashir et al. 2009; Aziz et al. 2010). According to Umar et al. (2010) for stabilized leachate, the COD content generally ranges between 5,000 and $20,000 \mathrm{mg} / \mathrm{L}$. The $\mathrm{BOD}_{5} / \mathrm{COD}$ ratio provides a good estimate of the state of the leachate and this ration for young leachate is generally between 0.4 and 0.5 (Kurniawan et al. 2006). The presence of concentrated pollutants in leachate has become one of the major issues to the landfill operator in obeying strict regulations for the safe disposal of leachate. Normally, the existence of high levels of pollutants such as ammonia in landfill leachate over a long period of time leads to a motivated algal growth, decreased performance of biological treatment systems, accelerated eutrophication, promoted dissolved oxygen depletion, and increased toxicity of living organisms in water bodies (Aziz et al. 2010). 
Various process applications such as aerobic and anaerobic biological degradation, chemical oxidation, chemical precipitation, coagulation-flocculation, activated carbon adsorption and membrane processes have been reported by various authors (Aziz et al. 2010; Halim et al. 2009; Aghamohammadi et al. 2006; Deng and Englehardt 2006). Anaerobic treatment is one of the treatments in biological process which is ideally fitted for the pre-treatment of high strength wastewaters that are typical of many industrial facilities for the removal of the bulk of effluent containing high concentrations of COD, BOD and heavy metals. In favour of anaerobic treatment, biodegradation is carried out by the microorganisms, which can degrade organic compounds to carbon dioxide and sludge under aerobic conditions and to biogas (a mixture comprising chiefly $\mathrm{CO}_{2}$ and $\mathrm{CH}_{4}$ ) under anaerobic conditions (Ghasimi et al. 2010). Effective microorganism (EM) technology identified as one of the biological treatment that comprises the most effective application for heavy metal removal in industrial wastewaters (Zhou et al. 2008). Historically, EM was first discovered by Teruo Higa of the University of the Ryukyus in Japan (Higa and Parr 1994). Initially, Higa and Parr investigated the microorganisms that were useful in crop farming as they were seen as alternatives to the use of pesticides and fertilizers (Zhou et al. 2008). However, as far as the authors concern, technology of EM or anaerobic organism is mostly being used in pig, cattle, dairy, and poultry farming for purification of the wastewater (Higa and Parr 1994; Joo et al. 2006). The main activity in the anaerobic process is the creation of an antioxidant environment by anaerobic organisms, which is deemed crucial to the enhancement of the solid-liquid separation in cleaning water practice. However, its usage and the effectiveness on industrial wastewater such as leachate is very far limited and documented. Therefore, this study was carried out to determine the feasibility of anaerobic organism inoculation in biological treatment of stabilized landfill leachate. The main purpose of the existing research is to investigate the effect of leachate parameters removal namely $\mathrm{COD}, \mathrm{NH}_{3}-\mathrm{N}$ and colour by anaerobic organism cultures. The efficiencies of $\mathrm{COD}, \mathrm{NH}_{3}-\mathrm{N}$ and colour removal were tested via different $\mathrm{pH}$ of leachate sample, dosage and contact time of anaerobic organism via laboratory experimental set up.

\section{Materials and methods}

Anaerobic organism preparation

Anaerobic organism solution was procured from Seberang Perai Municipal Council (Malaysia). The preliminary experimental work for obtaining the optimum ratio of brown sugar/fruit waste/distilled water conducted towards the removal of $\mathrm{COD}, \mathrm{NH}_{3}-\mathrm{N}$ and colour. The livelihood of the anaerobic organisms was also tested at the longest possible of preliminary experiment so that the microbial activity in the leachate sample lasts longer. To prepare anaerobic organism activated solution (AOAS), a ratio of 1:3:10 which was: 1 part of molasses/brown sugar; 3 parts of fruit waste; and 10 parts of distilled water were used. The mixture was amalgamated in a Teflon container and mixed thoroughly. The AOAS was fermented for 12 weeks. The survival of the microorganisms was largely dependent by the temperature of the environment. Therefore, the prepared mixtures were kept under minimum temperature fluctuations without direct sun light exposure. The off-gassing process occurred during the 7 days of fermenting with the released of carbon dioxide $\left(\mathrm{CO}_{2}\right)$. The entire process of fermentation was strictly monitored. In addition, the cover of the tank was ensured tightly closed to avoid generation of mold. The $\mathrm{pH}$ value was observed at the final duration of fermentation. $\mathrm{A} \mathrm{pH}$ value in the range of 3-4 indicated that the fermentation process has completed. Next, the anaerobic organisms were kept in an airtight container to keep it anaerobic prior to use. Fundamentally, the activated anaerobic organism suspension is a mixture of molasses (brown sugar) and anaerobic organism in free chlorinated water or rice rinse water which provides the minerals for the multiplication of the microorganisms (Mohamad Yatim et al. 2009). The activated anaerobic organisms were then fermented in an anaerobic environment for 7-10 days of incubation. Prior to the experimental works, each of the containers was rinsed with $10 \%(\mathrm{v} / \mathrm{v}) \mathrm{HCL}$ and then deionised with water to remove background effects of the medium.

\section{Identification of anaerobic organism}

Identification of anaerobic organisms was carried out according to the manual (Gerhardt 1994) and the procedure recommended by effective microorganism (EM) Research Organization (Okinawa, Japan). Theoretically, anaerobic organisms are rich with selected species of microorganisms, which can be commonly found in many ecosystems, including lactic acid bacteria (LAB), yeasts, actinomycetes photosynthetic bacteria, and other types of organisms. The analyses were done by diluting fermented materials in phosphate buffer ( $\mathrm{pH} \mathrm{7.0)}$ at appropriate levels and then spread-plated onto an appropriate agar media and incubated at $25-30{ }^{\circ} \mathrm{C}$ at least 1 week prior to observing the morphological and physiological characteristics. Initial laboratory investigation indicated that microbial groups of lactic acid bacteria, yeast and total bacteria count of $1.6 \times 10^{7}, 1.0 \times 10^{4}$ and $1.2 \times 10^{7} \mathrm{cfu} / \mathrm{mL}$, respectively, exists in the solutions. 
Table 1 Solid waste characteristics at PBLS

\begin{tabular}{ll}
\hline $\begin{array}{l}\text { Waste } \\
\text { characteristics }\end{array}$ & $\begin{array}{l}\text { Amount } \\
(\%)\end{array}$ \\
\hline Food & 40 \\
Plastic & 22 \\
Paper & 10.5 \\
Metals & 2.5 \\
Glass & 3.25 \\
Textile & 3.5 \\
Others & 18.25 \\
Total & 100 \\
\hline
\end{tabular}

Leachate sampling

The leachate used in the experiment was collected from Pulau Burung Landfill Site (PBLS), which is situated in the North West of Malaysia. PBLS started its operation in 1991 as a semi-aerobic system complying with Level II sanitary landfill standards by establishing a controlled tipping technique. The site receives 1,800 tonnes of domestic waste daily which origins from Penang Island and Perai district. Table 1 shows the characteristics of the solid wastes at PBLS. In 2001, the landfill was upgraded to a Level III sanitary landfill by employing controlled tipping with leachate recirculation (Aziz et al. 2010). The site has a natural marine clay liner with daily covers practices. Characteristically, PBLS has surpassed more than 20 years of operation which in the methanogenic phase, and the leachate produced is referred to as mature, "stabilized" leachate (Bashir et al. 2009). The darkcoloured liquid, with high concentrations of COD and ammonium, and a low $\mathrm{BOD}_{5} / \mathrm{COD}$ ratio is another indicator of stabilized leachate. The leachate sample was collected from September 2010 until March 2011. The samples were transported to the laboratory, and stored in a cold room at $4{ }^{\circ} \mathrm{C}$ to minimize biological and chemical changes prior to the experimental use (Bashir et al. 2010). The sampling procedure and preservation of samples were done according to the Standard Methods for the Examination of Water and Wastewater (APHA 2005). $\mathrm{pH}$ of the leachate sample was measured on-site using portable $\mathrm{pH}$ meter (Hach, sens ion 1, USA). The characteristics of the raw leachate from the oxidation pond of PBLS are shown in Table 2.

\section{Experimental procedure}

The study was focused on the preliminary determination of the condition that provides the optimum condition of anaerobic organisms in treating leachate. Prior to the experimental works, each of the containers was rinsed with $10 \%(\mathrm{v} / \mathrm{v}) \mathrm{HCL}$ and then deionised with water to remove the background effects of the medium. Three different aspects of the experimental procedure were as follows:

\section{Influence of $\mathrm{pH}$}

To investigate the influence of $\mathrm{pH}$ by anaerobic organism in the leachate sample, six containers of $20-\mathrm{cm}$ length and $10-\mathrm{cm}$ height with a total volume of $4,000 \mathrm{~mL}$ made of Plexi glass were used. The containers were filled with 1,500 $\mathrm{mL}$ raw leachate sample and $\mathrm{pH}$ was adjusted from 5 to 9 for each of the containers by either $0.1 \mathrm{~N}$ hydrochloric acid $(\mathrm{HCl})$ or $0.1 \mathrm{~N}$ sodium hydroxide $(\mathrm{NaOH})$. Then, anaerobic organisms were added to leachate at ratio of 1:10 (150 mL of anaerobic organism) using measuring cylinder. The solution was stirred with a glass rod thoroughly to avoid chemical reaction with the leachate sample and the anaerobic organism activities in the container. A net grating was installed on the top of each container to allow anaerobic activity with the surrounding environment throughout the experimental period. The containers were kept for 24 days to ensure complete reaction between leachate sample and anaerobic organisms and the percentage removal of COD, $\mathrm{NH}_{3}-\mathrm{N}$ and colour were eventually measured.

\section{Influence of dosage of anaerobic organism}

Different dosage of anaerobic organisms at optimum $\mathrm{pH}$ was mixed in five containers each with the exact volume of

Table 2 Raw leachate characteristics

\begin{tabular}{|c|c|c|c|c|c|c|c|c|}
\hline Parameters & 1 & 2 & 3 & 4 & 5 & 6 & Average & DOE standard \\
\hline $\mathrm{pH}$ & 7.81 & 7.67 & 7.34 & 7.65 & 7.12 & 7.51 & 7.52 & $5.5-9.0$ \\
\hline Ammoniacal nitrogen $(\mathrm{mg} / \mathrm{L})$ & 1,335 & 1,374 & 1,554 & 1,207 & 1,274 & 1,187 & 1,322 & 5 \\
\hline $\mathrm{BOD}_{5}(\mathrm{mg} / \mathrm{L})$ & 302 & 287 & 269 & 280 & 242 & 273 & 276 & 20 \\
\hline $\mathrm{COD}(\mathrm{mg} / \mathrm{L})$ & 1,420 & 1,374 & 1,271 & 1,429 & 1,238 & 1,457 & 1,365 & 400 \\
\hline $\mathrm{BOD}_{5} / \mathrm{COD}$ & 0.21 & 0.21 & 0.21 & 0.20 & 0.20 & 0.19 & 0.20 & 0.05 \\
\hline Colour (ADMI) & 1,568 & 1,547 & 1,761 & 1,644 & 1,543 & 1,455 & 1,586 & 200 \\
\hline Zinc $(\mathrm{mg} / \mathrm{L})$ & 3.0 & 2.5 & 2.6 & 3.5 & 2.9 & 2.8 & 2.9 & 2.0 \\
\hline Iron $(\mathrm{mg} / \mathrm{L})$ & 5.9 & 5.2 & 6.9 & 5.1 & 4.9 & 4.3 & 5.3 & 5.0 \\
\hline $\mathrm{SS}(\mathrm{mg} / \mathrm{L})$ & 258 & 237 & 249 & 298 & 301 & 168 & 250 & 100 \\
\hline
\end{tabular}


1,500 $\mathrm{mL}$ leachate sample. Different dosage ratio of 1:25, $1: 20,1: 15,1: 10$, and 1:5 which were $60,75,100,150$, and $300 \mathrm{~mL}$ of anaerobic organisms were filled in five containers, respectively, and kept under ambient air for 24 days. A net grating was installed on top of each container to allow anaerobic activity with the surround environment. The containers were kept in normal air condition in the range of $25-30{ }^{\circ} \mathrm{C}$ and the percent removal of leachate parameters was measured for $\mathrm{COD}, \mathrm{NH}_{3}-\mathrm{N}$ and colour, respectively.

\section{Influence of contact time}

To investigate the effect of removal efficiency of COD, by organic organisms, fixed amount of anaerobic organisms at optimum $\mathrm{pH}$ were prepared in 24 containers. A net grating was installed on top of each container to allow anaerobic activity with the surround environment. The sample was kept under normal air condition from day 1 to day 24 regimes. At the elapse of each set contact time, the treated leachate was filtered and analyzed for $\mathrm{COD}, \mathrm{NH}_{3}-\mathrm{N}$ and colour, respectively.

\section{Analytical method}

Treated leachate samples were first filtered by using $0.45 \mu$ GC-50 glass micro fibre filters (Advantec, Japan) to retain fines particles from passing through. COD was measured using Calorimetric Method (5220-D) whereby the concentration of $\mathrm{NH}_{3}-\mathrm{N}$ was measured based on the Nesslerization Method (Method: 8038) using UV spectrophotometer (HACH DR 2500, USA). Colour measurements were described as true colour, filtered using $0.45 \mu$ GC-50 (Advantec, Japan) assayed at $455 \mathrm{~nm}$ using DR 2500 HACH spectrophotometer. Method No. 2120C reports colour in platinum-cobalt ( $\mathrm{Pt}-\mathrm{Co}$ ), the unit of colour being produced by $1 \mathrm{mg}$ platinum/L in the form of the chloroplatinate ion (Al-Hamadani et al. 2011).

\section{Results and discussions}

\section{Raw leachate characteristics}

Table 1 illustrates some of the leachate characteristics at PBLS. Even though the samples were collected on different days or at different times, the leachate characteristics demonstrate similar fashion and were largely comparable for most of the parameters. The average $\mathrm{pH}$ value of the leachate samples is 7.52. According to Umar et al. (2010), the $\mathrm{pH}$ of young leachate was less than 6.5 , while for old landfill, the leachate has $\mathrm{pH}$ higher than 7.5. Initial low $\mathrm{pH}$ was due to high concentration of volatile fatty acids
(VFAs). Similarly, stabilized leachate shows fairly constant $\mathrm{pH}$ with little variations and it may range between 7.5 and 9 . The presence of significant amount of $\mathrm{NH}_{3}-\mathrm{N}(1,322 \mathrm{mg} / \mathrm{L})$ in the leachate indicates degradation of soluble nitrogen due to the decomposed waste. As a result, the concentration of $\mathrm{NH}_{3}-\mathrm{N}$ increases with the increase in age of the landfill which was due to hydrolysis and fermentation of nitrogenous fractions of biodegradable refuse substrate (Umar et al. 2010). Higher concentration of $\mathrm{NH}_{3}-\mathrm{N}$ enhances algae growth and promotes eutrophication due to decrease in dissolved oxygen content. Further, nitrification also leads to motivated algal growth, decreased performance of biological treatment systems, accelerated eutrophication, promoted dissolved oxygen depletion and increased toxicity of living organisms in water bodies (Aziz et al. 2010). According to Kurniawan et al. (2006), ammoniacal nitrogen was ranked as a major toxicant to living organisms, as established by various toxicity analyses using bioassays such as Salmo gairdnieri and Oncorhynchus nerka. The average values for $\mathrm{BOD}_{5}$ and COD were 276 and $1,365 \mathrm{mg} /$ $\mathrm{L}$, respectively. Meanwhile, the calculated $\mathrm{BOD}_{5} / \mathrm{COD}$ ratio was in the ratio of 0:20. In general, The BOD/COD ratio indicates the changes in the amount of biodegradable compounds in the leachate (Warith 2002). Based on the ratio, it shows that the leachate was poorly biodegradable. The low BOD/COD ratio (0:20) also shows that the leachate was stable and difficult to be further degraded biologically (Foul et al. 2009). The high value of $\mathrm{pH}$ and low concentrations of $\mathrm{COD}, \mathrm{BOD}_{5}$ and heavy metals indicate that the leachate was in the phase of methane fermentation and classified as anaerobic phase (Salem et al. 2008). Normally, at the early stage of landfill operation, the presence of heavy metals are significant because of higher metal solubility whereby low $\mathrm{pH}$ caused by production of organic acids (Kulikowska and Klimiuk 2008). The colour concentration was reported as $1,586 \mathrm{mg} / \mathrm{L}$, which was due to the low biodegradability of dissolved organic constituents in the leachate. Slow process of decomposition of buried waste has induced the percolation of liquid with the refuse. Therefore, dark-coloured liquid is an indicator of saturated organic content in the leachate. Overall, the leachate characteristics did not meet the permissible limit declared under Environmental Quality (Control of Pollution From Solid Waste Transfer Station and Landfill) Regulations 2009 (PU(A) 433) Second Schedule (Regulation 13) from Department of Environment, Malaysia.

\section{Optimum pH}

Since the large majority of bacteria present growth optima at or near neutral $\mathrm{pH}$ values, most laboratory-based biodegradation studies have been carried out in this $\mathrm{pH}$ range. Figure 1 shows the variation of $\mathrm{pH}$ adjustment of leachate 


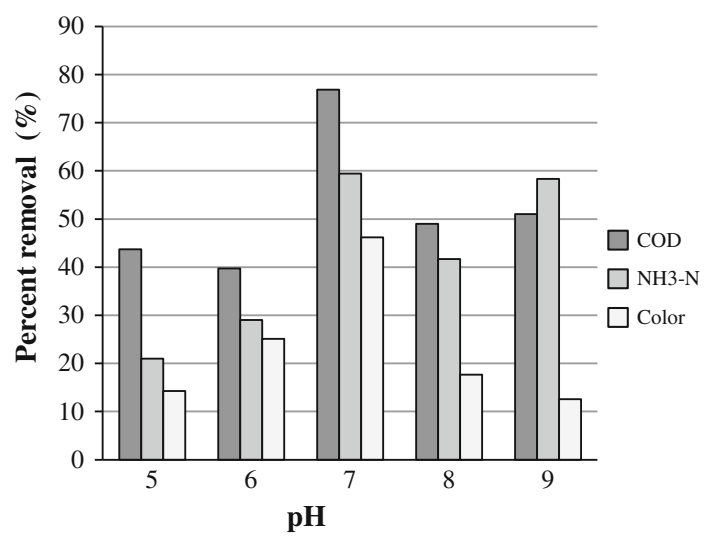

Fig. 1 Influence of $\mathrm{pH}$ for the removal of $\mathrm{COD}, \mathrm{NH}_{3}-\mathrm{N}$ and colour

sample to the leachate parameters removal. From the figure, it was shown that anaerobic organisms played a significant role in removal efficiency of leachate parameters. By lowering the $\mathrm{pH}$ of leachate sample, COD percentage removal was increased from 39.7 to $43.7 \%$. Under acidic condition, all organic compounds were fully oxidized to carbon dioxide. In this case, although anaerobic organisms are not an oxidizing agent, microorganisms in the solution dissolved thoroughly in leachate sample that are responsible for the degradation of the organic content. Furthermore, the reduction of COD was due to the organic strength of the leachate which is affected by the reduction of the methanogenic bacteria. Increasing $\mathrm{pH}$ from 8 to 9 would lead to a slight increment of the latter from 49 to $51 \%$. Lowering $\mathrm{pH}$ of leachate sample reduced the amount of dissolved oxygen needed by aerobic biological organisms in leachate sample to break down the organic material present, which was known as the worse condition of anaerobic organisms' survival. In contrast, normal $\mathrm{pH}$ of leachate leads to higher removal of COD which comprises of $76.8 \%$. It was assumed that anaerobic organisms would tolerate in the normal $\mathrm{pH}$ of leachate. Similar finding was observed for the case of $\mathrm{NH}_{3}-\mathrm{N}$ removal. Under acidic condition, $\mathrm{NH}_{3}-$ $\mathrm{N}$ removal was observed below $29 \%$, whereas slight increment removal was recorded when $\mathrm{pH}$ increased from 8 to 9. According to Rashid and West (2007), most microorganisms exhibit optimal growth at $\mathrm{pH}$ values between 6 and 8 and most could not tolerate at pH levels above 9 or below 4 . The phenomenon of free ammonia inhibition of ammonia oxidizing bacteria (AOB) and nitrite oxidizing bacteria (NOB) also were found affected by $\mathrm{pH}$ adjustment. High $\mathrm{pH}$ would increase the free ammonia concentration and inhibits nitrifying activity, especially when the $\mathrm{NH}_{4}{ }^{+}-\mathrm{N}$ level was high (Zhang et al. 2007). Moreover, increasing the $\mathrm{pH}$ of leachate attributed to the higher concentration of $\mathrm{NH}_{3}-\mathrm{N}$ generated from biodegradation process due to parts of protein were biodegraded and some nitrogen species were transferred to the form of $\mathrm{NH}_{3}$ after bioreaction. These results suggest that the bacteria produce enzymes whose optimal activity occurs in different $\mathrm{pH}$ values. For the colour removal, the highest reduction was achieved when the leachate $\mathrm{pH}$ at $7(46.2 \%)$. As the $\mathrm{pH}$ of the leachate increased to alkaline state, further reduction was observed. This was due to condition of the organisms in the mixture of leachate which is susceptible when the $\mathrm{pH}$ of the leachate was normal. Since the present work intended to investigate the ability of anaerobic organisms to remove pollutants in a stationary condition of leachate sample, the excess negatively charged hydroxide ions have to compete with inorganic constituents available in the leachate. Therefore, colour removal was not favourable in this condition. This result was in agreement with the work reported by Oliveira et al. (2009).

\section{Optimum dosage}

Figure 2 shows the influence of anaerobic dosage to the removal of leachate parameters. Briefly, removal of COD and $\mathrm{NH}_{3}-\mathrm{N}$ were directly proportional to the anaerobic organism dosage to a certain level. The presence of anaerobic organism in the leachate sample at ratio 1:15 (100 mL) could remove up to $42 \%$ of the COD concentration followed by dosage of $75 \mathrm{~mL}$ (1:20) and $100 \mathrm{~mL}$ (1:15), respectively. Meanwhile, the anaerobic organism dosage of $150 \mathrm{~mL}(1: 10)$ and $300 \mathrm{~mL}(1: 5)$ could only remove COD concentration at 17.6 and $4.2 \%$, respectively. Therefore, based on the observation from the figure, the highest removal of COD concentration achieved when $100 \mathrm{~mL}$ of anaerobic organism was introduced in the leachate sample. Generally, as the dosage of anaerobic organism increased, the removal of COD concentration was increased due to the increasing of active bacteria and organic acid in anaerobic organism including Bacillus subtilis which decomposes and digests the organic residuals in leachate. Meanwhile, the lactic acid bacteria increase the carbohydrate metabolism

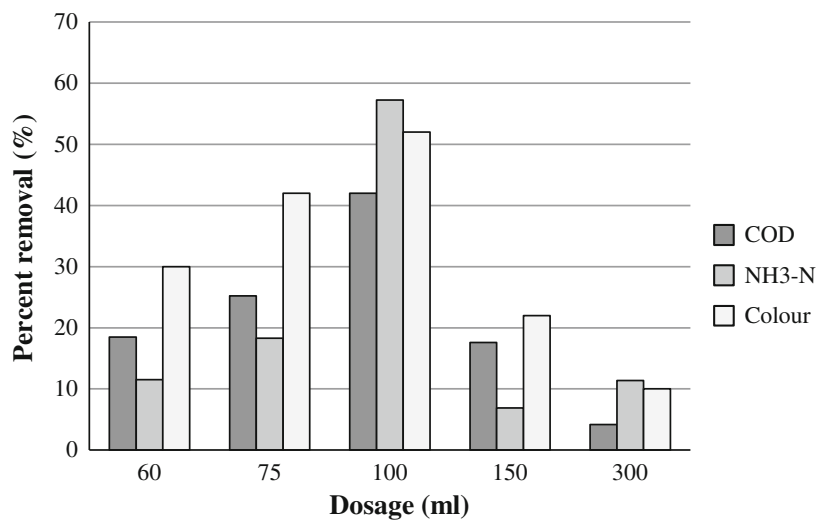

Fig. 2 Influence of dosage for the removal of $\mathrm{COD}, \mathrm{NH}_{3}-\mathrm{N}$ and colour 
by producing lactic acid and other antimicrobial products. Those antimicrobial products having antibacterial properties that inhibited the growth of pathogens and other nonbeneficial microorganisms during the biodegradation of organic particle in leachate sample. From the figure, the removal efficiency of $\mathrm{NH}_{3}-\mathrm{N}$ was reduced when incrementing the amount of anaerobic organisms was introduced. At dosage of $100 \mathrm{~mL}$, highest removal of $\mathrm{NH}_{3}-\mathrm{N}$ was achieved at $57.21 \%$. In contrast, reducing dosage of anaerobic organisms resulted low removal of $\mathrm{NH}_{3}-\mathrm{N}$. Low removal in $\mathrm{NH}_{3}-\mathrm{N}$ concentration leads to motivated algal growth, accelerated eutrophication and rendered the livelihood of the microorganisms without food availability. These reductions could be attributed to the microbial utilization of these nutrients. Inorganic nitrogen variation should be similar to COD, since COD is consumed to oxidize the inorganic chemicals. The removal pattern for colour was observed similar to $\mathrm{COD}$ and $\mathrm{NH}_{3}-\mathrm{N}$, respectively. The highest colour reduction was observed when the anaerobic organism dosage was $100 \mathrm{~mL}(52 \%)$. As the dosage of the anaerobic organism increases, lower removal of the colour was observed at dosage 1:5. Initially, the culture mixtures available were adequate during the microbial activity in the leachate mixture. Consequently, addition of anaerobic organisms was found to attribute mainly towards the stabilized biological activity of the leachate sample (Zouboulis et al. 2001). This would hinder the breakdown process of dissolved organic constituents which deplete the microbial activity in the leachate that leads to formation of dark liquid in the container.

\section{Optimum contact time}

The removal efficiency of COD and $\mathrm{NH}_{3}-\mathrm{N}$ is shown in Fig. 3. At initial interval of treatment, slight removal was observed for $\mathrm{COD}$ and $\mathrm{NH}_{3}-\mathrm{N}$ where only 1.5 and $8.1 \%$ reductions were recorded. The data show that the treatment process provides a consistent high efficiency of COD removal until day 12 accounted for $42 \%$. Similar observation was also recorded in the case of $\mathrm{NH}_{3}-\mathrm{N}$ where the removal percentage was increased from 1.5 to $42.1 \%$ at day 14. Despite the fluctuations of $\mathrm{COD}$ and $\mathrm{NH}_{3}-\mathrm{N}$ concentrations on the first 14 days of treatment, the removal pattern shows a gradual reduction for the case of COD. Hence, a slow rate of biodegradation might have caused the COD increase over the time. From the figure, a slow dropped off percent removal of $\mathrm{NH}_{3}-\mathrm{N}$ occurred at day 18. Increasing the contact time of anaerobic organisms allowed the microorganism in the leachate sample mixed assisted by acclimatize with the indigenous microbial population in the leachate. As the period of leachate sample prolonged, $\mathrm{COD}$ and $\mathrm{NH}_{3}-\mathrm{N}$ removal was observed reduced significantly. The differences in reducing abilities of each leachate may be attributed to differences in bacteria species, bacterial biomass concentration or organic type, as well as landfill conditions such as waste content and landfill age. Similarly, microorganisms are often sensitive to their environment. Likewise, high concentration of $\mathrm{NH}_{3}-\mathrm{N}$ increased nitrification reduced the rate of biodegradation of leachate. According to Umar et al. (2010), higher concentrations of ammonia are also known to enhance algal growth, promote eutrophication due to decreased dissolved oxygen. Hence, microbial activity was further depleted over time. In addition, longer contact time of anaerobic organisms and leachate sample will reduce the ability of different microorganism to react efficiently with the leachate pollutants, since more oxygen depleted in the containers. The mechanism involved suggests that as anaerobic organism was a mixed culture of many species of microorganisms, some of which can transform from $\mathrm{NH}^{4+}$
Fig. 3 Influence of contact time for the removal of COD, $\mathrm{NH}_{3}-\mathrm{N}$ and colour

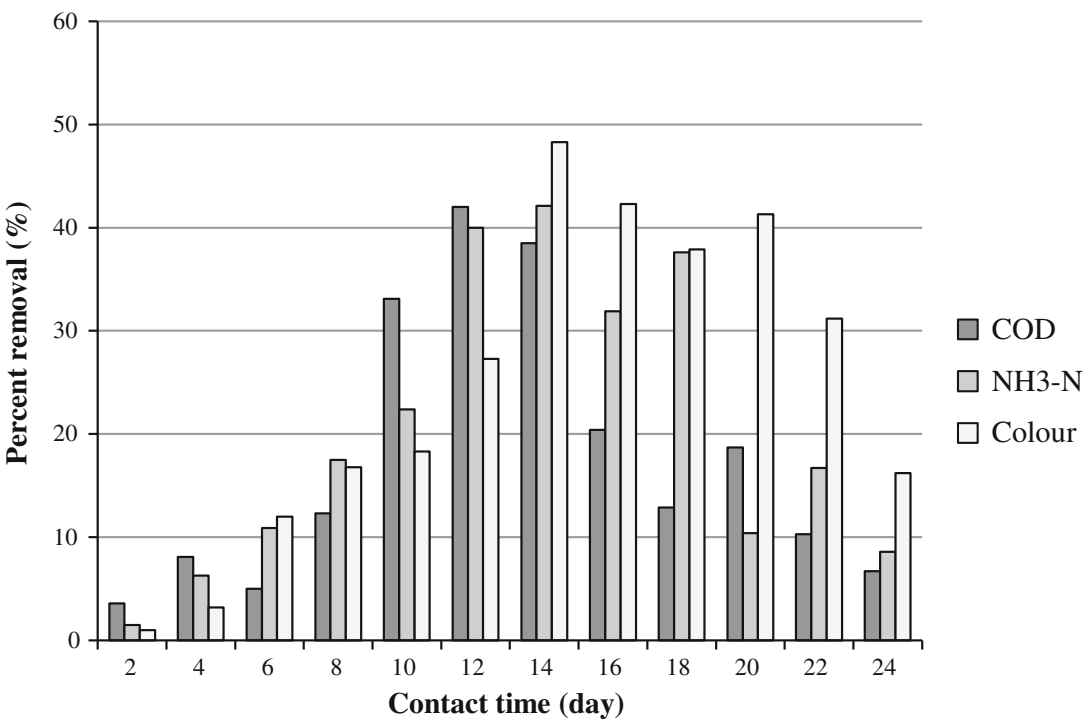


Table 3 Optimum variable condition of anaerobic organisms

\begin{tabular}{lllllll}
\hline \multicolumn{2}{l}{ Optimum condition } & & & \multicolumn{3}{l}{ Percent removal } \\
\cline { 7 - 8 } \cline { 6 - 7 } $\mathrm{pH}$ & Dosage & Contact time (day) & & COD & $\mathrm{NH}_{3}-\mathrm{N}$ & Colour \\
\hline 7 & $100 \mathrm{~mL}$ & 14 & 65.5 & 60.2 & 46.3 \\
\hline
\end{tabular}

to $\mathrm{NO}^{-}$, thereby decreasing the potential for $\mathrm{N}$-fraction (Javaid 2010). Meanwhile, it was observed that the highest colour removal was recorded at 14 days $(48.3 \%)$. Although the reduction of colour was fluctuated after 14 days, the anaerobic organisms continue to decolorize until the 24 days of experiment at slow rate. The possible justification of this behaviour was governed by the rejuvenation of microbial activity in the leachate sample. When the period of incubation increases, longer duration of active organisms in the leachate sample with the surround environment which promotes the active cell of microorganism activity entirely.

\section{Optimum variable condition}

In assessing the optimum variable conditions of the anaerobic organisms, the evaluation of the preliminary experiment was prerequisite. Since the variable conditions produce different removal efficiency, the selection of the variables was based on the highest removal of COD, $\mathrm{NH}_{3}-\mathrm{N}$ and colour. Table 3 shows the optimum condition of anaerobic organism preparation. It can be observed that the optimum condition of the anaerobic organism achieved at $\mathrm{pH} \mathrm{7,} \mathrm{dosage} \mathrm{of} 100 \mathrm{~mL}$ and required 14 days to reduce the $\mathrm{COD}, \mathrm{NH}_{3}-\mathrm{N}$ and colour pollutants to $65.5,60.2$ and $46.3 \%$, respectively. The final concentrations of the pollutants are: COD, $470 \mathrm{mg} / \mathrm{L} ; \mathrm{NH}_{3}-$ $\mathrm{N}, 526 \mathrm{mg} / \mathrm{L}$; colour, 851 ADMI. We can observe that the final concentration of the treated leachate sample still exceeded the permissible discharge limit regulated by Malaysia DOE (COD, $400 \mathrm{mg} / \mathrm{L} ; \mathrm{NH}_{3}-\mathrm{N}, 5 \mathrm{mg} / \mathrm{L}$; colour, 200 ADMI).

\section{Conclusions}

In this study, biological treatment of leachate by anaerobic organisms under ambient condition was investigated. The biological treatment process was found to be feasible for treating the leachate from stabilized landfill. $\mathrm{COD}, \mathrm{NH}_{3}-\mathrm{N}$ and colour-removal efficiencies under neutral $\mathrm{pH}$ of leachate sample were found in the range of 76.8, 54.4 and $46.2 \%$, respectively. Increasing the dosage of anaerobic organisms led to a higher removal of COD from 18.5 to $42 \%$, respectively. In addition, when equal dosage was tested for $\mathrm{NH}_{3}-\mathrm{N}$, up to $57 \%$ removal was recorded. As for the colour removal, similar pattern was observed for the removal efficiency. In this case, $100 \mathrm{~mL}$ dosage of anaerobic organism was found optimum with $52 \%$ colour reduction. However, further increasing of anaerobic organism resulted in drastic reduction of these parameters between 4.2 and $11.4 \%$, respectively, for $\mathrm{COD}, \mathrm{NH}_{3}-\mathrm{N}$ and colour. Meanwhile, removal pattern of $\mathrm{COD}, \mathrm{NH}_{3}-\mathrm{N}$ and colour increased from day 2 and reached maximum at day 14. However, fluctuation pattern was observed starting at day 16 until day 24 for $\mathrm{COD}$ and $\mathrm{NH}_{3}-\mathrm{N}$, respectively. Meanwhile, the optimum condition of the anaerobic organism achieved at $\mathrm{pH} 7$, dosage of $100 \mathrm{~mL}$ and required 14 days to reduced $\mathrm{COD}, \mathrm{NH}_{3}-\mathrm{N}$ and colour pollutants to $65.5,60.2$ and $46.3 \%$, respectively. It also indicates that the actual contact time was reduced from 24 to 14 days when the replication of the experiment was conducted, which proves that anaerobic organism could shorten the process of microbial activity in leachate sample. As a result, the application of anaerobic organisms was effective for biological treatment of landfill leachate that simultaneously reduces high concentration of pollutants from landfill. However, the optimal conditions of AOAS were not able to reduce the concentration of leachate sample to a stipulated permissible discharge limit enforced by Malaysia DOE. The partial treatment system such as aeration process can be employed to improve oxidation state of organic content in the leachate sample provided that ammonia stripping is designated after the AOAS treatment to assist denitrification of ammonia content. Since AOAS is a biological process, the application of this treatment can be designated in the pre-treatment of leachate. In this case, the AOAS treatment can be conducted in a rector supplied with sprinkler system. At a certain time of period, the AOAS will be emitted in the reactor by the sprinkler system and the microbial activity occurs when the aerated leachate flows into the reactor. Conclusively, the AOAS is considered as partial treatment system for leachate remediation process considering its ability to reduce leachate contents. However, more investigation should be conducted to explore the ability of AOAS in full-scale reactor system so that the ability of this microbial system can be optimized.

Open Access This article is distributed under the terms of the Creative Commons Attribution License which permits any use, distribution, and reproduction in any medium, provided the original author(s) and the source are credited. 


\section{References}

Aghamohammadi N, Aziz HA, Isa MH (2006) Removal of iron from semi-aerobic landfill leachate by activated Sludge-activated carbon process. UTP Publication http://eprints.utp.edu.my/ 1492/1/ Assessed 10 May 2012

Al-Hamadani YAJ, Yusoff MS, Umar M, Bashir MJK, Adlan MN (2011) Application of psyllium husk as coagulant and coagulant aid in semi-aerobic landfill leachate treatment. J Hazard Mater 190:582-587

APHA (2005) Standard method for the examination of water and wastewater, 21st edn. American Public Health Association, Washington

Aziz SQ, Aziz HA, Yusoff MS, Bashir MJK, Umar M (2010) Leachate characterization in semi-aerobic and anaerobic sanitary landfills: a comparative study. J Environ Manage 91:2608-2614

Bashir MJK, Isa MH, Kutty SRM, Awang ZB, Aziz HA, Mohajeri S, Farooqi IH (2009) Landfill leachate treatment by electrochemical oxidation. Waste Manage 29:2534-2541

Bashir MJK, Aziz HA, Yusoff MS, Aziz SQ, Mohajeri S (2010) Stabilized sanitary landfill leachate treatment using anionic resin: treatment optimization by response surface methodology. J Hazard Mater 182:115-122

Deng Y, Englehardt JD (2006) Treatment of landfill leachate by the Fenton process. Water Res 40:3683-3694

Foul AA, Aziz HA, Isa MH, Hung YT (2009) Primary treatment of anaerobic landfill leachate using activated carbon and limestone: batch and column studies. Int J Environ Waste Manag 4:282-298

Gerhardt P (1994) Methods for general and molecular bacteriology. American Society for Microbiology, Washington

Ghasimi SMD, Idris A, Chuah TG, Tey BT (2010) Semi-continuous anaerobic treatment of fresh leachate from municipal solid waste transfer station. Afr J Biotechnol 8:2763-2773

Halim AA, Aziz HA, Megat Johari MA, Ariffin KS (2009) Removal of ammoniacal nitrogen and COD from semi-aerobic landfill leachate using low-cost activated carbon zeolite composite adsorbent. Int J Environ Waste Manag 4:399-411

Higa T, Parr JF (1994) Beneficial and effective microorganisms for a sustainable agriculture and environment. International Nature Farm ing Research Centre Atami, Japan. http://www.emturkey.com.tr/ TR/dosya/1-314/h/54-parrhigabkltcf120on20em.pdf. Assessed 15 May 2012

Javaid A (2010) Beneficial microorganisms for sustainable agriculture. Genetic Eng Biofertil Soil Quality Organic Farm. doi: 10.1007/978-90-481-8741-6_12
Joo HS, Hirai M, Shoda M (2006) Piggery wastewater treatment using Alcaligenes faecalis strain No. 4 with heterotrophic nitrification and aerobic denitrification. Water Res 40:3029-3036

Kjeldsen P, Barlaz MA, Rooker AP, Baun A, Ledin A, Christensen TH (2002) Present and long-term composition of MSW landfill leachate: a review. Crit Rev Env Sci Tec 32:297-336

Kulikowska D, Klimiuk E (2008) The effect of landfill age on municipal leachate composition. Bioresource Technol 99: 5981-5985

Kurniawan TA, Lo W, Chan G (2006) Physico-chemical treatments for removal of recalcitrant contaminants from landfill leachate. J Hazard Mater 129:80-100

Mohamad Yatim J, Rahman WA, Aizan W, Sam M, Rahman A (2009) Characterisation and effects of the effective microorganics (EM) and industrial waste (IW) materials as a partial mixture in concrete.UTM Press, Skudai. http://www.eprints.utm. my/9710/. Accessed 12 May 2012

Oliveira PL, Duarte MCT, Ponezi AN, Durrant LR (2009) Use of Bacillus pumilus CBMAI 0008 and Paenibacillus sp. CBMAI 868 for colour removal from paper mill effluent. Braz J Microbiol 40:354-357

Rashid M, West J (2007) Dairy wastewater treatment with effective microorganisms and duckweed for pollutants and pathogen control. Nato Sec. doi:10.1007/978-1-4020-6027-4_10

Renou S, Givaudan JG, Poulain S, Dirassouyan F, Moulin P (2008) Landfill leachate treatment: review and opportunity. J Hazard Mater 150:468-493

Salem Z, Hamouri K, Djemaa R, Allia K (2008) Evaluation of landfill leachate pollution and treatment. Desalination 220:108-114

Umar M, Aziz HA, Yusoff MS (2010) Variability of parameters involved in leachate pollution index and determination of LPI from four landfills in Malaysia. Int J Chem Eng. doi:10.1155/ 2010/747953

Warith M (2002) Bioreactor landfills: experimental and field results. Waste Manage 22:7-17

Zhang S, Peng YZ, Wang SY, Zheng SW, Guo J (2007) Organic matter and concentrated nitrogen removal by shortcut nitrification and denitrification from mature municipal landfill leachate. J Environ Sci 19:647-651

Zhou S, Wei C, Liao C, Wu H (2008) Damage to DNA of effective microorganisms by heavy metals: impact on wastewater treatment. J Environ Sci 20:1514-1518

Zouboulis A, Loukidou M, Christodoulou K (2001) Enzymatic treatment of sanitary landfill leachate. Chemosphere 44:11031108 